\title{
CONSUMER'S SATISFACTION AND BEHAVIOUR TOWARDS PERSONAL FINANCING
}

\author{
Noormariana Mohd Din ${ }^{1}$ \\ Doctor Philosophy Candidate, \\ Faculty of Entrepreneurship and Business, Universiti Malaysia Kelantan. \\ (Email: mariana.md@umk.edu.my) \\ Assoc. Prof. Dr. Mohammad b. Ismail ${ }^{2}$ \\ Faculty of Entrepreneurship and Business, Universiti Malaysia Kelantan. \\ Ruslee Nuh $^{3}$ \\ Doctor Philosophy Candidate, \\ Faculty of Entrepreneurship and Business, Universiti Malaysia Kelantan.
}

Received date: $18-06-2019$

Revised date: $21-07-2019$

Accepted date: $31-08-2019$

Published date: 15-09-2019

To cite this document: Mohd Din, N., Ismail, M., \& Nuh, R. (2019). Customer's Satisfaction and Behaviour Towards Personal Financing. International Journal of Entrepreneurship and Management Practices, 2 (7), 61-79.

DOI: $10.35631 /$ ijemp.27008

\begin{abstract}
The unprecedented changes in the financial market have put a great pressure on financial service providers. As more competitive financial products and services emerge in the market, financial institutions have no choice, but to enhance their competitive advantages. Thus, consumer behaviour in purchasing products and services must really be understood by the service providers. Unfortunately, the literature on customer satisfaction and purchase decision is hardly seen in finance industry. This paper originally develops a model of the relationship between consumer satisfaction and purchase decision in finance industry focusing on personal finance. The mediating role of customer satisfaction in the purchase decision is emphasized in this research model. This model had been used to focus purchase decisions by adapted Theory Planned Behaviour (TPB). A clear understanding of the relationship attitude, subjective norms and perceived behavioural control towards purchase behaviour had found by previous research. But lack of studies focused on the small-medium enterprises (SME's) that nowadays have become a platform for the economy in Malaysia. Hence, this conceptual model had focused on SME's behaviour in selecting personal finance. The conceptual model offers insight into the general nature of a recovery that specifically to the understanding of SME's behaviour as well as in purchase personal loan.
\end{abstract}

Keywords: Consumer Behaviour, Customer Satisfaction, Purchase Decision, Personal Finance 


\section{Introduction}

\section{Background Of The Study}

In social science, consumer finance is an emerging area of inquiring spanning development of disciplines by raises significant questions about cognition, risk taking, self-control, rational decision making, time preferences and social theory. Undoubtedly, this view behaviour offers potential solutions towards any problematic in finance regarding consumer issue. However, it still remains a patchwork among funders (Collins, 2010). Therefore, it important to current studies consider the main factor in consumer finance behaviour so that it will provide insights for practitioners, policymakers and consumer who are potentially react to future shifts in the personal finance behaviour (Perry \& Morris, 2005). Some researchers had investigated the customer preferences, behaviour and intention towards financial, such as (Hanudin Amin, 2014; Trenton Milner \& Ameer, 2013; Haque, 2010; Archana, 2009). Regrettably, they are only focused on the intention in purchasing by explored only Theory of Planned Behaviour (TPB). Moreover, lack of previous studies had investigated the main factor that influences the intention in the future and level of satisfaction. The level of satisfaction may be influenced by the purchase intention or behaviour. Previously, some researchers had found that the intention is influenced by service and brand but they did not expand the field of research to relate the factors of purchase intention to customer satisfaction (Kisang, 2012; Manshor, 2011; Haque, 2010; Heugnes, 2004; Wang, 2003; Applebaum, 1951; Dodds, 1985). It is difficult to find the previous researches that focused on any products or transactions and made comparisons between two types of institutions. The previous researchers only highlighted the service quality and satisfaction of conventional and Islamic banks (Riadh, 2011; Mansor, 2005) but little gave the specific focus to products such as loan, investment instrument or any of the transaction except focused on the credit card market and home financing (Hanudin, 2014; A. R. Hanudin, 2011; Shannon, 2009; Zuroni, 2012). Therefore, this study focuses on personal financing which is one of the products that are provided by both financial institutions. The researcher chooses personal financing as the indicator of consumer behaviour finance and satisfaction since it presents high risk and offers high profit to the banks (Stepanova \& Thomas, 2002).

Admittedly, nowadays personal finance is becoming increasing because of innovation and deregulation of the financial sector, and the consequences of insufficient financial literacy that are concentrated among the low income and small medium enterprises (SME's) (Servon \& Kaestner, 2008). In reality, since that the SMEs have played very important roles in the development of many Asian countries, latest researcher had focuses on financing SMEs in Nigeria by examines the various financing option available to the SMEs (Gbandi \& Amissah, 2014). One of the external factors affecting the growth of SMEs is access to finance where view in aspects macroeconomics and market environment issues. It can be seen that, SMEs is no doubt that access to finance of crucial importance for the on-going and sustainable growth and profitability through facilitating the creation of new business and nurturing the innovation process (M. M. S. Ahmad, Ahmad, Kahut, \& Murtaza, 2012). Previous researcher had reviewed the literature in the various financing sources of SMEs by focused the financial behaviour (Abdulsaleh \& Worthington, 2013). In general, the characteristics of SMEs affect their financial decisions and behaviour and ultimately the firm's performance and growth. In this context, the literature has identified several characteristics peculiarly related to the SMEs sector as factors influencing the financial behaviour of firms in this sector. These include firm size and age, ownership type and legal form, geographical location, industry sector and asset structure (reflecting the ability to provide collateral) (Abouzeedan, 2003).

This SMEs sector necessitates better understanding of financial behaviour and practices since SMEs increasing towards economic contribution in country (Abdulsaleh \& Worthington, 
2013). Moreover, the SMEs are now an increasing important source of profitability for the banks. As discussed above, the researcher found that how important the personal financing headed for SMEs performance. For that reason, necessary for banker or financial institution to review and investigate the financing behaviour among SMEs. The research model extends theory of planned behaviour (TPB) (I. Ajzen, 1991), integrated with flow theory (Csikszentmihalyi, 1975; Fenton, 2006; Mackenzie, Hodge, \& Boyes, 2011; Takagi, 2009), the effects satisfaction from consumer research. TPB provides a theoretical foundation for this model. The research model aims to help examine the behavioural impacts of the major factors affecting on consumer behaviour in personal financing. These major factors include attitude, subjective norms and perceived behavioural control, satisfaction as a mediator variable influence the consumer behaviour in personal financing. This study will complete by a survey of SMEs all of whom have personal financing experience either from Islamic or conventional finance.

\section{Research Scope}

The scope of this paper is based on consumer's satisfaction and behaviour towards personal financing. The research's intent to investigate the factors that effect of behaviour and mediator among SME by presenting the mains constructs of Theory Planned Behaviour (TPB). In terms of respondents, this study focused on the individual borrower for personal finance among SME. Hence, this paper is conceptual paper, therefore, the researchers only providing the expected findings that explained detailed in the next section.

\section{Literature Review}

\section{Financial Industry and Personal Finance Review}

The financial sector acts as the profit organizations and their performance had measured by a host of financial indicators. The overall development of World Bank is reflecting by the economy's financial market (World Bank, 2013). It is found that the banking systems and stock markets enhance growth; growth is the main factor in poverty reduction. The growth such as increasing personal remittance from 2003 until 2012 is $\$ 479.2$ billion and the domestic credit provided by banking sector (\% of GDP) is 164.9\% increasing from 2003 until 2012 (World Bank, 2013). The increasing and strong performance in financial system enhances the reliability and accessibility of information that lowers transaction cost, which in turn bolsters resource allocation and economic growth (Nejatullah, 2002). The size and liquidity of stock market, the accessibility, stability and efficiency of financial systems; and international migration of workers which affect growth and social welfare in both sending and receiving countries act as an indicators of this performance (Development, 2012). The financial performance of an institution is can be affected by its performance along the service delivery, financial intermediation and product transaction. Such as, in the product category, personal banking or finance supported an immediate or long-term financing facility with a fixed repayment period granted to qualified individuals stipulated under the banks' terms and conditions.

Personal banking is the typical general purpose of loans. Normally the major reasons for applying the loan are for businesses, education, marriages or houses (BNM, 2010). According to Bank Islam Annual Report such as, BIMB (2011), the financing, advances and others had increased compared to those in 2010. Personal financing increased from RM 3,001,048,000.00 in 2010 to RM 3,786,432,000.00 in 2011. By 2012, it increased to RM 6,608,116,000.00 and this shows that the demand for personal banking is increasing over the years (BIMB, 2012). Bank Islam Berhad expects to maintain its robust growth. The bank will continue to grow its 
consumer financing products as well as focus on resilient industries, in particular those that are set to benefit from the Economic Transformation Programme (BIMB, 2012).

\section{Consumer Behavior Review}

In marketing practice and social science, the study of consumer behaviour as a sub discipline of marketing by aims to identifying how research can be applied (Pachauri, 2002). Two broad paradigms that consumer behaviour characterized: the positivist and the non-positivist (Pachauri, 2002). Economic behavioural, cognitive, motivational, trait, attitudinal, and situational perspectives acts as positivist paradigm. All this paradigm marks consumer behavior as an independent research field (Pachauri, 2002). In dissimilarity, the non-positivist paradigm takes the interpretive and postmodern perspective that started in the late 1980. By achieve a better understanding of consumer behavior with no specific intent, the non-positivism intend to use qualitative methodologies (Pachauri, 2002). Therefore, this study focusing on positivist research which is directed toward advancing the goals of marketing practice and moreover it had supported by (Pachauri, 2001) that recommend future research by identifying the paradigms shifts within the specific intent to influence consumer processes. Permitting to (Pachauri, 2002) review, there are several main research streams in the positivist paradigm and summarized as follows:

\section{Underlying the Theoretical Foundation for Consumer Behaviour}

\section{The Theory of Planned Behaviour (TPB)}

Ajzen (1991) introduced a further determinant of intention called perceived behavioural control. The theory proposes that there are three constructs that predict behaviour: attitude, subjective norms and perceived behavioural control, and it postulate set of relations among these three constructs and behavioural intention. The basic paradigms of TPB suggests that a particular behaviour will be performed if an individual believes (1) that such a behaviour leads to a valuable outcome (attitude); (2) that he/she will get approval from the reference group (subjective norms); and (3) that the resources, abilities and opportunities to perform the behaviour are available (perceived behavioural control).

\section{Attitude and SME's Behavior}

Attitude had found that a wonderful explanatory power in accounting for revolving credit use and petty installment use in debt behavior (Wang Lili, Lv Wei, \& Jiang Lin, 2011). Similarity in credit card review, the personal financial knowledge and attitude towards credit card practices among working adults had investigated in Malaysia. It originate concludes that gender, monthly income, personal financial knowledge and attitude influencing that credit card practice among working adults in Ipoh (Zuroni, 2012). Moreover, in global business and management research had surveyed the effect of consumer attitude towards environmental protection and knowledge of environmental issues, which affects actual purchase behavior. It exposed the positive and significant impact between attitude and consumers actual purchase behaviour but environment knowledge is not a major impact (Elham Rahbar, 2010). Therefore, based on these literatures, the first proposition as follow;

\section{P1: Attitude Significantly Give The Effect Toward SME's Behaviour}

\section{Subjective Norms and SME's Behavior}

In the credit card situation for finance, theory planned behaviour to include the construct of financial literacy. It found that subjective norms successfully predicted student's intention and behavioral to use credit cards (Kennedy, 2013). Other studies major in retail and distribution management, shown that significant subjective norms towards behavioral since the person fear 
social pressure form references. Moreover, the referents provide the guidance regarding an appropriate or beneficial behaviour in their society (Park \& Ha, 2012). Huda, Rini, Mardoni, and Putra (2012) had found muzakki's intention to pay zakah simultaneously significant influence by attitude, subjective norms and perceived behavioral control variables. Hence, according to previous literature, the next proposition as follows:

\section{P2: Subjective Norms Significantly Give The Effect Toward SME's Behaviour}

\section{Perceived Behavioral Control (PBC) And SME's Behavior}

In online purchasing behaviour perspectives, analysis of the data indicates that beliefs about trustworthiness positively affect attitudes toward buying online. Moreover, in turn positively affect purchasing behaviour it belief that positively affect perceived behavioral control, which in turn affects online purchasing behaviour (J. F. George, 2004). Besides that, electronic commerce adoption had significantly by done the longitudinal study, online consumer supports the e-commerce adoption model that reflect the positively effects from perceived behavioral control towards behaviour among e-commerce (Pavlou \& Fygenson, 2006). The preceding argument suggest next proposition as follow;

\section{P3: Perceived Behaviour Control (PBC) significantly give the effect toward SME's Behaviour}

\section{The Mediating Effects of Customer Satisfaction towards Relationship between Attitude, Subjective Norms, Perceived Behaviour Control and SME's Behaviour}

\section{Customer Satisfaction and SME's Behavior}

The satisfied customers are more likely to return to the same place for transactions and more willing to share their positive experiences with others (Chi, 2007). Positive experiences will present the word of mouth recommendations in terms of marketing that is considered the most reliable and one of the most sought after information sources for potential customers (Yoon, 2005). It important to note the impact of consumer satisfaction on behavioural intentions, such as intention to return and recommend, will be disproportionate for the different perspectives (Opperman.M, 1998). Moreover, Satisfaction relates to experiences of that state of a psychological process (Oliver, 1997). According to Crompton (1995), the experience that influences satisfaction is the psychological outcome arising from participation in the activities. Thus, the satisfaction refers to the emotional state of mind that result after a customer's exposure to the attributes of a provider's services. In addition, consumer satisfaction is the result of a consumer's perceptions of the value received in a transaction or relationship (Blanchard, 1994; Heskett, 1990). Following this, the definition put forward by Bitner (1994) is an adaptation of this study, which argues that the satisfaction is a consumer's post purchase evaluation and emotional response to the experiences provided by and associated with particular products or services purchased. Based on literature discussion above and respect to the TPB model, it calls for this study to develop framework as refer Figure 1.

\section{Conceptual Framework}

Based on the review of the literature and research problem, integrative the conceptual framework as illustrated in Figure 1 is developed. The study mainly focuses on SME's behaviour towards personal financing that primarily based on the TPB Model by (Ajzen, 1991). The customer satisfaction presenting as the mediator variable that may give the effect the relationship between attitude, subjective norms, perceived behavioural control and SME's behaviour. 


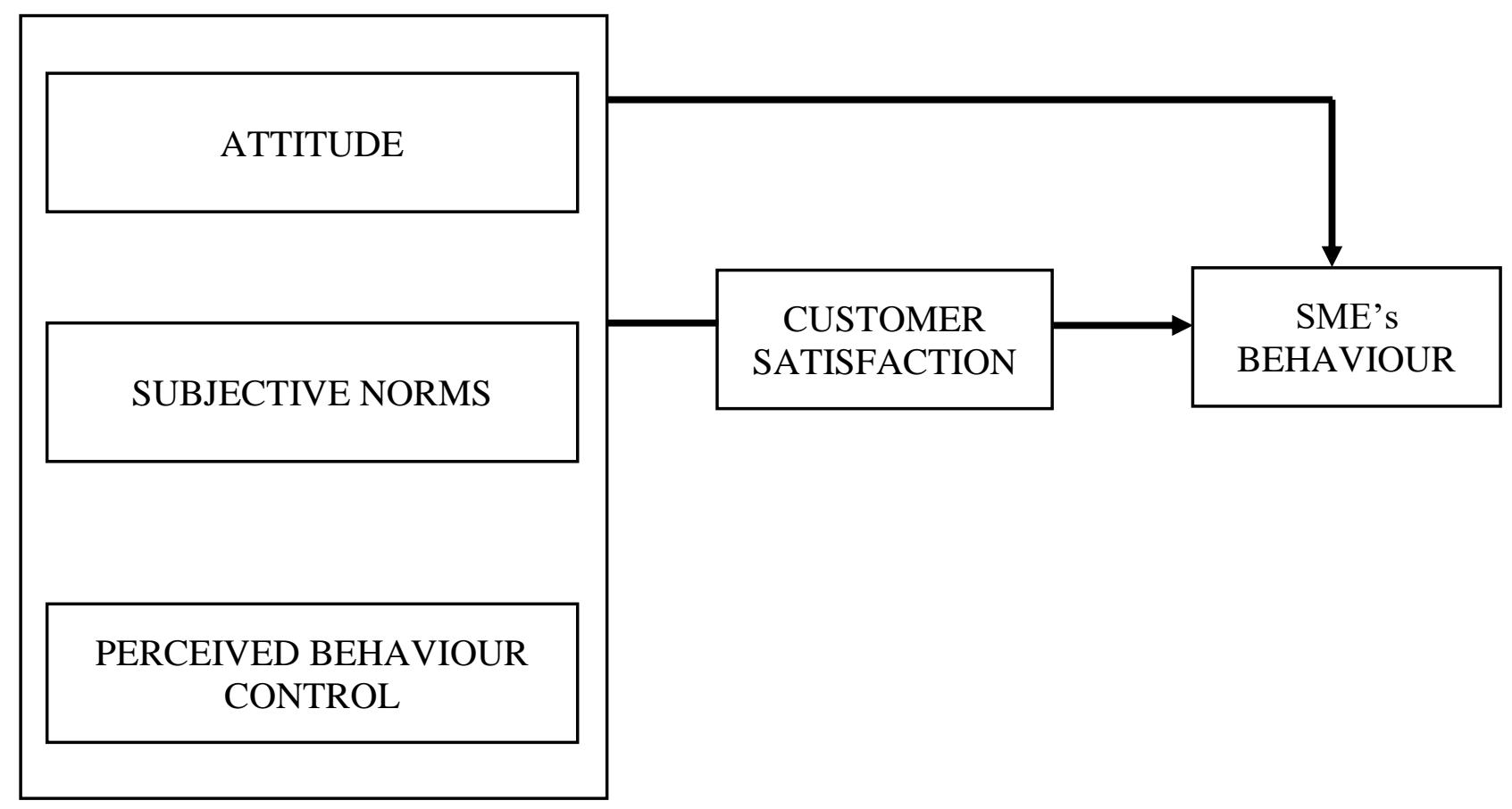

Figure 1: Conceptual Framework of Study

\section{Methodology}

This research will base in Malaysia. The unit of analysis in this study focused on the individual borrower by utilizing a self-assessment technique. This technique will apply by asking small medium enterprises (SMEs) who had applied the personal finance to state their level of agreement or disagreement with the statements in the questionnaire. Therefore, this study focused on the quantitative methods to understand human phenomena and to investigate and ascertain meanings that people apply to specific experience (Polkinghorne, 1992).

\section{Variables Measurement}

This study drive use designated structured questionnaire that had been found through extensive literature search, investigative personal interview and experience survey. According to G. A. J. Churchill, Iacobucci (2005b), the information sources (interviews and relevant literature search) provided the researcher of this study with a deeper knowledge by providing an "overall picture" of the experiences under investigation. In this study, the measurement of TPB constructs is based by previous work and listed as follows as summarize by Table 1 .

Table 1: Summarized Of Variables Measurement

\begin{tabular}{|c|ll|c|}
\hline Variables & \multicolumn{2}{|c|}{ Items } & \multicolumn{1}{c|}{ Sources } \\
\hline & Loyalty & (Pi1) & (Archana Kumar, 2009; Kisang \\
Consumer & Encourage others & (Pi2) & 2012; Konstantinos, 2001; \\
Purchase Behavior & Motivation & (Pi3) & Min Young Lee, 2008; \\
(PI) (DV) & Deal for long time & (Pi4) & Namkung, 2007; Patterson, \\
& Future action & (Pi5) & 2002) \\
\hline
\end{tabular}




\begin{tabular}{|c|c|c|}
\hline Attitude (ATT) & 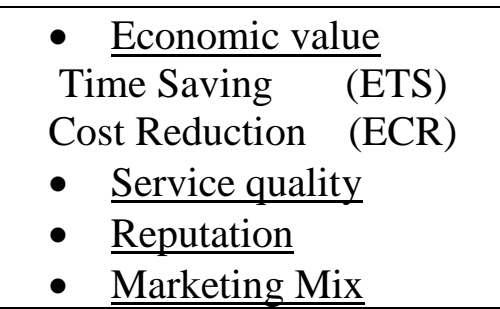 & $\begin{array}{l}\text { (Gefen, Karahanna, \& Straub, } \\
\text { 2003; D. J. Kim, Ferrin, \& Rao, } \\
\text { 2008; J. B. Kim, 2012) }\end{array}$ \\
\hline $\begin{array}{c}\text { Subjective Norms } \\
\text { (SN) }\end{array}$ & \begin{tabular}{ll}
\multicolumn{1}{l}{ Motivation } & \\
People & \\
- $\quad$ Normative & \\
Structure & \\
Family & (NS) \\
Friend & (NF) \\
Media & (NM) \\
\end{tabular} & $\begin{array}{l}\text { (I. Ajzen, 2002, 2011; Barnes, } \\
\text { 2014; L. Chen, 2009; J. F. } \\
\text { George, 2004; Huang, 2011) }\end{array}$ \\
\hline $\begin{array}{l}\text { Perceived } \\
\text { Behavioral } \\
\text { Control } \\
\text { (PBC) }\end{array}$ & $\begin{array}{l}\text { Difficulty } \\
\text { - Controllability } \\
\text { Necessary resources } \\
\text { Completely (NC) } \\
\begin{array}{ll}\text { - Self-Efficacy } \\
\text { Able } \\
\text { Confident } & \text { (SA) }\end{array}\end{array}$ & $\begin{array}{c}\text { (Liqiang Chen, 2009; Pavlou \& } \\
\text { Fygenson, 2006; Pavlou \& } \\
\text { Gefen, 2004) }\end{array}$ \\
\hline $\begin{array}{l}\text { Customer } \\
\text { satisfaction } \\
\quad(\mathrm{CS})\end{array}$ & $\begin{array}{ll}\text { First choice } & \text { (Cs1) } \\
\text { Price } & \text { (Cs2) } \\
\text { Positive thinking } & \text { (Cs3) } \\
\text { Happiness } & \text { (Cs4) } \\
\text { Feelings of acceptance(Cs5) }\end{array}$ & $\begin{array}{l}\text { (Gill, 2007; Kisang Ryu, 2012; } \\
\text { LaBarbera, 1983; Mittal, 2001; } \\
\text { Oh, 2000; Pantouvakis, 2008; } \\
\text { Parker, 2001; Yonggui, 2002) }\end{array}$ \\
\hline
\end{tabular}

\section{Study Population}

The researcher in this study was unable to access respondents' data from any banks. It had stated by the BAFIA Act 1989 under secrecy of banker (Section 27) regarding information and credit customers for the disclosure to the public. Therefore, the researcher had using face contacts is that the researcher tend to be professionally interested in the results and committed to making sure that the data are accurate (McGrath, 2001).

\section{Sample Size}

In making a decision on appropriate sample size, there is an investable trade-off between added information and added cost, time and resources. In the other words, the determination of the sample size must consider both statistical accuracy and cost. According to Sekaran (2005), a sample of one hundred to five hundred is large enough to generalize the population as refer Table 2.

Another rule that has been suggested is that a sample size of at least two hundred and not exceeding four hundred is adequate for statistical analysis using Structural Equation Modeling (SEM) (Hair, 2006). Therefore, the researcher often has to look for an alternative to SEM when this research models involve both reflective and formative structure. 
Table 2: Estimated Sample Size

\begin{tabular}{|l|c|}
\hline \multicolumn{1}{|c|}{ Description } & $\begin{array}{c}\text { Estimated sample } \\
\text { size }\end{array}$ \\
\hline $\begin{array}{l}\text { SEM model containing five (5) or fewer } \\
\text { constructs, each with more than three (3) items } \\
\text { (observed variables) and with high item } \\
\text { communalities (0.6 or higher) }\end{array}$ & $100-500$ \\
\hline $\begin{array}{l}\text { Any communalities are modest (0.45 - 0.55) or } \\
\text { the model contains construct with fewer than } \\
\text { three (3) items }\end{array}$ & $\begin{array}{c}\text { More on the order } \\
200\end{array}$ \\
\hline $\begin{array}{l}\text { The communalities are lower or the model } \\
\text { includes multiple under identified (fewer 3 } \\
\text { items) constructs }\end{array}$ & $\begin{array}{c}\text { Minimum sample } \\
\text { sizes of } 300 \text { or } \\
\text { more }\end{array}$ \\
\hline $\begin{array}{l}\text { Number of factors is larger than six (6), some } \\
\text { of which use fewer than three (3) items and } \\
\text { multiple low communalities }\end{array}$ & \begin{tabular}{c} 
Exceed 500 \\
\hline
\end{tabular} \\
\hline
\end{tabular}

\section{Data Analysis Procedures}

Based on the characteristics of this research, confirmatory factor analysis (CFA) with structural equation modelling was the appropriate technique rather than other multivariate analysis techniques (i.e., multiple regression analysis and exploratory factor analysis). It is important to note that the scale reliability and validity analysis techniques, which consisted of an examination of missing data, outliers, normality, factor analysis and Cronbach's alpha coefficient, hence, they are not described in this section. The entire test must be performed prior to multivariate analysis (i.e., SEM) so that measurements that produce weak results can be deleted. Next, the main statistical analysis technique employed to test the hypotheses formulated for the study, Structural Equation Modelling (SEM), is described. In order to do SEM analysis, AMOS 16.0 and Statistical Programme for the Social Sciences (SPSS) 14.0 for Windows software packages will used in this study.

\section{Significance Of Study}

It is hoped that this study will contribute to the literature of Consumer Behaviour Theories, namely the Theory of Reasoned Action and Theory of Planned Behaviour. First, this study has contributed to the recent and on-going debate on the factors that influence SMEs to choose the personal banking for capital sources for financial performance. Although many views have been generated by this debate, it is only focused on the satisfactions towards the service quality without expanding the knowledge to create a relationship between the satisfaction and the behaviour in purchasing personal banking.

The expectation result for this study also consider as main contribution. This study highlight the main factor that causes of SMEs in making their decision. Based on this field, it reflecting the strategies for finance and service industry to maintain their performance. The researcher found that this area of study will act as input for improvement of management within the financial institutions. This study offers more insights by incorporating Malaysians' perception towards Islamic finance in particular and by identifying the Islamic finance behaviour.

Moreover, this study will give some benefits in strategic management by identifying the characteristics of customers and developing marketing strategies to targeting the customers in the long run. 


\section{References}

Abdulsaleh, A. M., \& Worthington, A. C. (2013). Small and Medium-Sized Enterprises Financing: A Review of Literature. International Journal of Business and Management, $8(14), 36-54$.

Abouzeedan, A. (2003). Financing swedish small and medium-sized enterprises (SMEs): methods, problems and impact. Paper presented at the 43rd European Congress of the Regional Science Association, Jyväskylä, Finland.

Adewale, A. A., Yusuf, M. B. O., Ghani, G. M., Mydin Meera, A. K., \& Manap, T. A. A. (2012). The Role of Institutional Trust in the Adoption of Gold Dinar in Kelantan: An Empirical Analysis. Journal of Applied Sciences, 12(20), 2148-2155.

Agyapong, D., Agyapong, G. K. Q., \& Darfor, K. N. (2011). Criteria for Assessing Small and Medium Enterprises' Borrowers in Ghana. International Business Research, 4(4), 132138.

Ahmad, A., Rehman,K.U.,Safwan,N. (2011). Comparative study of Islamic and conventional banking in Pakistan based on customer satisfaction. African Journal of Business Management, $\quad$ 5, 1768-1773. http://www.academicjournals.org/ajbm/abstracts/abstracts/abstracts2011/4Mar/Ahma d\%20et\%20al.htm

Ahmad, M. M. S., Ahmad, E. P., Kahut, M. B. H. M. S., \& Murtaza, G. M. B. A. (2012). New Determination Of Factors Affecting The Growth Of Small And Medium Sized Enterprises In Pakistan. Interdisciplinary Journal of Contemporary Research In Business, 4(6), 513-530.

Ahmad Muhammad Gumel, M. A. O. (2013). Reflecting Customers' Innovativeness And Intention To Adopt Islamic Banking In Nigeria. Business and Management Quarterly Review, 4(3), 27-37.

Ahmed Shahriar, F., \& Polonsky, M. J. (2013). Predicting Bangladeshi financial salespeople's ethical intentions and behaviour using the theory of planned behaviour. Asia Pacific Journal of Marketing and Logistics, 25(4), 655-673.

Ajzen. (1991). Theory of Planned Behavior. Organizational Behavior And Human Decision Process. 179-189.

Ajzen, I. (1991). The theory of planned behavior. Organizational behavior and human decision processes, 50(2), 179-211.

Ajzen, I. (2002). Constructing a TPB questionnaire: Conceptual and methodological considerations.

Ajzen, I. (2011). Constructing a theory of planned behavior questionnaire. Unpublished manuscript. Retrieved, 1 .

Ajzen, I., \& Madden, T. J. (1986). Prediction of goal-directed behavior: Attitudes, intentions, and perceived behavioral control. Journal of experimental social psychology, 22(5), 453-474.

Ajzen, I. F. (1980). Understanding attitudes nad predicting behavior. Eaglewood Cliff,NJ: Prentice Hall.

Al Ziadat, M. T. (2014). Applications of Planned Behavior Theory (TPB) in Jordanian Tourism. International Journal of Marketing Studies, 6(2), 105-116.

Aladwani, A. M. (2003). A deeper look at the attitude-behavior consistency assumption in information systems satisfaction research. The Journal of Computer Information Systems, 44(1), 57-63.

Alexandre, M., \& Dubois, P. (2000). Polymer-layered silicate nanocomposites: preparation, properties and uses of a new class of materials. Materials Science and Engineering: $R$ : Reports, 28(1), 1-63. 
Ali Raza Hamid. (2014). A Study on the Relationship between Consumer Attitude, Perceived Value and Green Products. Iranian Journal of Management Studies (IJMS), 7(2), 315328.

Ali, S. S. (2004). Islamic Banking Finance: Fundametals and Contemporary Issue. Paper presented at the Conference Islamic Research and Training Instituion, Brunei.

Ameer, I. (2013). Consumer attitude towards Islamic financing. International Journal of Marketing and Technology, 3(10).

Anderson, E. W., \& Sullivan,M. (1993). The antecendents and consequences of consumer satisfaction for firms. Marketing Science, 12, 125-143.

Anderson, J. C., \& Gerbing, D.W. (1988). Structural equation modelling in practice: a review and recommended two step approach. Psychological Bulletin, 103(411-423).

Anthony, R., Ezat, W. S., Al Junid, S., \& Moshiri, H. (2011). Financial Management Attitude and Practice among the Medical Practitioners in Public and Private Medical Service in Malaysia. International Journal of Business and Management, 6(8), p105.

Arasli, H., Smadi,S.M.,\& Katircioglu. (2005). Customer service quality in the Greek Cypriot. Journal of Managing Service Quality, 15(1), 41-56.

Archana Kumar, Y.-K. K., Lou Pelton. (2009). Indian consumers purchase behavior toward US versus local brands. International Journal of Retail \& Distribution Managament, 37(6), 510-526.

Atkinson, R. L. (1996). Hilgard's introduction to psychology (Vol. 12): Harcourt Brace College Publishers Philadelphia PA.

Awang, Z. (2012). A Handbook on SEM Strucutral Equation Modeling: SEM USING AMOS GRAPHIC. Universiti Teknologi MARA: Publication Centre, UPENA

Azmi. (2012). Getting the Pictures Malaysia Financial Sector: Blueprint Strengthening Our Future.

Bagozzi, R. P., \&Yi, Y. (1988). On evaluation of structural equation models. Journal of the Academy of Marketing Science, 16(1), 74-94.

Bakar, D. A. (2012). Malaysian Financial Institution Invited to Expand Islamic Banking in Pakistan. http://www.malaysiandigest.com/business/42827--malaysian-financialinstitutions-invited-to-expand-islamic-banking-in-pakistan.html

Bandura, A. (1994). Self-efficacy: Wiley Online Library.

Barber, N., Kuo, P.-J., Bishop, M., \& Jr, R. G. (2012). Measuring psychographics to assess purchase intention and willingness to pay. Journal of Consumer Marketing, 29(4), 280292. doi: 10.1108/07363761211237353

Barnes, A. (2014). Predicting Consumer Intention to Adopt Electronic Payment Systems Using the Theory of Reasoned Action. (3633176 D.B.A.), Northcentral University, Ann Arbor. Retrieved from http://search.proquest.com/docview/1611235723?accountid=51152 ProQuest Dissertations \& Theses Global database.

Barry, T. E., \& Howard, D. J. (1990). A review and critique of the hierarchy of effects in advertising. International Journal of Advertising, 9(2), 121-135.

Battistich, V., Schaps, E., Watson, M., Solomon, D., \& Lewis, C. (2000). Effects of the Child Development Project on students' drug use and other problem behaviors. Journal of Primary Prevention, 21(1), 75-99.

Beeho, A. J., \& Prentice, R. . (1997). Conceptualizing the experiences of heritage tourists: a case study of New Lanark World Heritage Village. Tourism management, 18(2), 7587.

Biswas, S. (2009). Job Satisfaction and Job Involvement as Mediators of the Relationship Between Psychological Climate and Turnover Intention. South Asian Journal of Management, 16(1), 27-43.

Bitner, M. J., Hubert. (1994). Encounter satisfaction versus overall satisfaction versus quality: the customer's voice. London: Sage Publications. 
Blanchard, R. E., \& Galloway,R.L. (1994). Quality in retail banking. international journal of service industry management, 5(4), 5-23.

BNM, B. N. M. (2010). Islamic Banking \& Takaful. Retrieved 23 September 2012, from http://www.bnm.gov.my/index.php?ch=fs_mfs\&pg=fs_mfs_bank

Bolton, R. N. D. (1991). a multistage model of customer's assessments of service quality and value. Journal of consumer research, 17, 375-384.

Boyd. (1991). Strategic planning and finacial performance: A meta-analytical review. Journal of Management Studies, 28.

Brown, T. A. (2006). Confirmatory factor analysis for applied research: Guilford Press.

Burton-Jones, A., \& Hubona, G. S. (2006). The mediation of external variables in the technology acceptance model. Information \& Management, 43(6), 706-717.

Butcher, K. (2005). Differential impact of social influence in the hospitality encounter. International Journal of Contemporary Hospitality Management, 17(2/3), 125-13

Butt, M. M., \& Aftab, M. (2013). Incorporating attitude towards $<$ IT $>$ Halal $</$ IT $>$ banking in an integrated service quality, satisfaction, trust and loyalty model in online Islamic banking context. International Journal of Bank Marketing, 31(1), 6-23.

Buzzle. (2010). High Risk Unsecured Personal loans. Retrieved 14 October 2012, from http://www.buzzle.com/articles/high-risk-unsecured-personal-loans.html

Byne, B. M. (2001). Structural equation modelling with AMOS: Concepts, application and programming. NJ: Mahwah.

Carlson, J., \& O'Cass, A. (2010). Exploring the relationships between e-service quality, satisfaction, attitudes and behaviours in content-driven e-service web sites. The Journal of Services Marketing, 24(2), 112-127. doi: http://dx.doi.org/10.1108/08876041011031091

Carraher, S. M. (2011). Turnover prediction using attitudes towards benefits, pay, and pay satisfaction among employees and entrepreneurs in Estonia, Latvia, and Lithuania. Baltic Journal of Management, 6(1), 25-52. doi: http://dx.doi.org/10.1108/17465261111100905

Cengiz, E., \& Yayla,H.E. (2007). The effect of marketing mix on positive word mouth communication:Evidence from accounting offices in Turkey. Innovative Marketing, 3(4), 74-86.

Chan, D. K. (2003). Study: Islamic Banking in Malaysia Lacks Major Participation from Muslims. Selangor: Deloitte.

Chang, C.-C. (2004). The effect of choice and perceived control on customer satisfaction: The psychology of service recovery. (3166602 Ph.D.), Purdue University, Ann Arbor. Retrieved from http://search.proquest.com/docview/305151440?accountid=51152 ProQuest Dissertations \& Theses Global database.

Chang, L.-Y., Lee, Y.-J., Chien, C.-L., Huang, C.-L., \& Chen, C.-Y. (2010). The Influence of Consumer's Emotional Response and Social Norm on Repurchase Intention: a Case of Cigarette Repurchase in Taiwan. Journal of International Management Studies, 5(2), 21-30.

Chatzoglou, P. D., \& Eftichia, V. (2009). Knowledge-sharing behaviour of bank employees in Greece. Business Process Management Journal, 15(2), 245-266. doi: http://dx.doi.org/10.1108/14637150910949470

Chen, C.-F. (2009). Mechanism, transmission and enforcement of social norms: A study of college students' drinking behavior. (3401848 Ph.D.), Washington State University, Ann Arbor. Retrieved from http://search.proquest.com/docview/305018743? accountid=51152 ProQuest Dissertations \& Theses Global database. 
Chen, H.-S., \& Hsieh, T. (2011). A Study of Antecedents of Customer Repurchase Behaviors in Chain Store Supermarkets. Journal of International Management Studies, 6(3), 1-11.

Chen, L. (2009). ONLINE CONSUMER BEHAVIOR: AN EMPIRICAL STUDY BASED ON THEORY OF PLANNED BEHAVIOR. (Degree of Doctor of Philosophy), University of Nebraska. Retrieved from http://search.proquest.com/docview/304948609/previewPDF/B80A59B6621940D6P $\mathrm{Q} / 1$ ?accountid=51152

Chen, L. (2012). An exploratory study into the adoption of Internet banking in Mainland China. (3587965 Ph.D.), Southern Illinois University at Carbondale, Ann Arbor. Retrieved from http://search.proquest.com/docview/1433824902?accountid=51152 ProQuest Dissertations \& Theses Global database.

Chi, C. G. Q., \& Qu, H. (2007). Examining the structural relationship of destination image, tourist satisfaction and destination loyalty: An integrated approach. Tourism Management.

Chih-Chung (2005). Discussion on the Behavior Intention Model of Consumer Online Shopping. Journal of Business and Management, 11(1), 41.

Churchill, G. A. J., \& Surprenant,C. (1982). An investigation into the determinants of customer satisfaction. journal of marketing research, 19, 491-504.

Churchill, G. A. J., Iacobucci. (2005a). Marketing research: Methodological foundations. Mason: Thomson: South Western.

Churchill, G. A. J., Iacobucci. (2005b). Marketing research:Methodological foundations. Mason: Thomson South Western.

Collins. (2010). Consumer Financial Behavior: Integrating Disciplines to Understand Fundamental Economic Activity at the Household Level. from http://www.cfs.wisc.edu/briefs/Collins2011_ConsumerFinancialBrief.pdf

Corby, N. H., Schneider-Jamner, M. (1996). using the theory of planned behavior to predict intention to use condoms male and female injection drug users. Journal of Applied Social Psychology, 26, 52-75.

Cowen, T. (1990). Mutual Fund Banking:A Market Approach. Cato Journal, 10, 223-237.

Crompton, J. L., \& Love,L.L. (1995). The predictive validity of alternative approaches of evaluating quality of a festival. Journal of Travel Research 34(1), 11-24.

Cronin, J. J., \& Taylor,S.A. (1992). Measuring service quality as assessment of the SERVQUAL dimension. Journal of Retailing, 66(1), 33-55.

Cronin Jr, J. J., Brady, M. K., \& Hult, G. T. M. (2000). Assessing the effects of quality, value, and customer satisfaction on consumer behavioral intentions in service environments. Journal of retailing, 76(2), 193-218.

Csikszentmihalyi, M. (1975). Play and intrinsic rewards. Journal of humanistic psychology.

Currás-Pérez, R., Ruiz-Mafé, C., \& Sanz-Blas, S. (2013). Social network loyalty: evaluating the role of attitude, perceived risk and satisfaction. Online Information Review, 37(1), 61-82. doi: http://dx.doi.org/10.1108/14684521311311630

D.Hoyer, W., \&Maclnnis,D.J. (2008). Consumer Behavior. USA: South Western.

Development, G. F. (Producer). (2012). Financial Development. World Bank. Retrieved from http://econ.worldbank.org/WBSITE/EXTERNAL/EXTDEC/EXTGLOBALFINREPO RT/0,,contentMDK:23268767 pagePK:64168182 piPK:64168060 theSitePK:88160 97,00.html

Dodds, W. B., \&Monroe, K.B. (1985). The effect of brand and price information on subjective product evaluation. Advances in consumer research, 12, 85-90.

Elham Rahbar. (2010). The Malaysian Consumer and the Environment: Purchase Behavior. Global Business and Management Research: An International Journal, 2(4), 323-336. 
Eugene, M. C. E. (2002). Financial Management: Theory and Practice United Kingdom: Thomson Learning Academic Resources.

Fauziah Md. Taib, T. R., Dzuljastri Abdul Razak. (2008). Factors influencing intention to use diminishing partnership home financing. International Journal of Islamic and Middle Eastern Finance and Management, 1(3), 235-248.

Fenton, L. (2006). Adventure education and Csikszentmihalyi's flow theory: A critical analysis of stress and optimal experience as learning tools. (1441075 M.A.), Prescott College, Ann Arbor. Retrieved from http://search.proquest.com/docview/304906772?accountid=51152 ProQuest Dissertations \& Theses Global database.

File, R. A. P. (1992). Positive word of mounth:Customer satisfaction and buyer Behavior. International Journal of Bank marketing, 10(1), 25-29.

Fishbein, M., \& Ajzen, I. (1975). Belief, attitude, intention, and behavior:An introduction to theory and research. Reading,MA: Addison Wesley.

Fishbein, M., \& Manfredo,MJ. (1992). A theory of behavior of change Champaign II: Sagamore.

Fornell, C. (1992). A national customer satisfaction barometer. Journal of marketing research, $18,39-50$.

Fornell, C., \& Larcker D.F. (1981). Evaluating structural equation models with unobservable variables and measurement erro. Journal of marketing research, 18(1), 39-50.

Frank R. Kardes, M. L. C., \& Cline, T. W. (2011). Consumer Behavior Retrieved from http://bookzz.org/book/2222877/cc318c/?_ir=1

Fstep. (2010). Financial Sector Talent enrichment Programme: Conventional banking Handbook. Kuala Lumpur: Institut Bank Bank Malaysia.

Galan-ladero, M. M., Galera-casquet, C., \& Wymer, W. (2013). Attitudes towards causerelated marketing: determinants of satisfaction and loyalty. International Review on Public and Non - Profit Marketing, 10(3), 253-269. doi: http://dx.doi.org/10.1007/s12208-013-0103-y

Gallarza, M. G., \& Saura,I.G. (2006). Value dimensions, perceived value, satisfaction and loyalty:investigation of university student's travel behavior. tourism management, 27 , 437-452.

Gbandi, E. C., \& Amissah, G. G. (2014). FINANCING OPTIONS FOR SMALL AND MEDIUM ENTERPRISES (SMEs) IN NIGERIA. European Scientific Journal, 10(1).

Gefen, D., Karahanna, E., \& Straub, D. W. (2003). Trust and TAM in online shopping: an integrated model. MIS quarterly, 27(1), 51-90.

George, B. P., \& Hegde, P. G. (2004). Employee attitude towards customers and customer care challenges in banks. International journal of bank marketing, 22(6), 390-406.

George, J. F. (2004). The theory of planned behavior and Internet purchasing. Internet research, 14(3), 198-212.

Gilaninia, S., Alipour, H., Rahpeyma, P., \& Mousavian, S. J. (2011). Effective Factors on Behavior Tendency in the Acceptance of Electronic Banking Based on Planned Behavior Model (TPB). International Journal of Business Administration, 2(4), 54.

Gill, D., Byslma, B., \& Oushan,R. (2007). Customer perceived value in a cellar door visit: theimpact on behavioural intention. International Journal of wine Business Research, 19(4), 257-275.

Gopi, M., \& Ramayah, T. (2007). Applicability of theory of planned behavior in predicting intention to trade online. International Journal of Emerging Markets, 2(4), 348-360. doi: http://dx.doi.org/10.1108/17468800710824509

Hair, J. F., Black, W.C (2006). Multivariate data analysis. New Jersey: Pearson Prentice Hall. 
Hallowell, R. (1996). The relationships of customer satisfaction, customer loyalty and profitability: an empirical study. International Journal of Service Industry Management, 7(1), 27-42S.

Hanif, M. (2011). Differences and similarities in Islamic and conventional Banking. International Journal of Business and Social Science, 2(2).

Hanudin. (2014). Consumer acceptance of Islamic home financing. International Journal of Housing Markets and Analysis, 7(3), 302-332.

Hanudin Amin, A. R. A. R., Dzuljastri Abdul Razak. (2014). Consumer acceptance of Islamic home financing. International Journal of Housing Markets and Analysis, 7(3), 307-332.

Hanudin, A. R. (2011). Determinants of customers' intention to use Islamic personal financing. Journal of Islamic Accounting and Business Research, 2(1), 22-42.

Haron, H., Saniza Binti, S., Jayaraman, K., \& Ishak, I. (2013). Factors Influencing Small Medium Enterprises (SMES) in Obtaining Loan. International Journal of Business and Social Science, 4(15).

Hee, S. P. (2000). Relationships among attitudes and subjective norm: Testing the theory of reasoned action across cultures. Communication Studies, 51(2), 162-175.

Heskett, J. A., Sasser,W.e.,\& Hart,C.W. (1990). Service Breakthrough. New York: The Free Press.

Hirschman, E. C., \& Holbrook, M. B. (1982). Hedonic consumption: emerging concepts, methods and propositions. The Journal of Marketing, 92-101.

Hoffman, F. J., \& Freud, S. (1957). Freudianism and the literary mind: Louisiana State University Press Baton Rouge.

Holmes-Smith, P., Coote \& Cunningham. (2006). Structural Equation Modeling: From fundamental to Advanced topics. Melbourne: Streams.

Horne, J. C., \& M.Wachowicz,J. (2008). Fundamentals of Financial Management: Prentice Hall.

Hoyer, W. D., \& Macinnis. (2001). Consumer behavior. Boston: Houghton Mifflin Company.

$\mathrm{Hu}, \mathrm{B}$. (2003). The impact of destination involvement on travelers' revisit intentions. Unpublished Ph.D: Purdue University, University states.

Huang, D. S. X. (2011). Research on Online Shopping Intention of Undergraduate Consumer in China--Based on the Theory of Planned Behavior. International Business Research, $4(1)$.

Huda, N., Rini, N., Mardoni, Y., \& Putra, P. (2012). The Analysis of Attitudes, Subjective Norms, and Behavioral Control on Muzakki's Intention to Pay Zakah. International Journal of Business and Social Science, 3(22).

Iqbal, M. M., K. (2005). Thirty Years of Islamic Banking: HIstory Performance and Practice. Wiley: Chichester

Jen, W., Tu, R., \& Lu, T. (2011). Managing passenger behavioral intention: an integrated framework for service quality, satisfaction, perceived value, and switching barriers. Transportation, 38(2), 321-342. doi: http://dx.doi.org/10.1007/s11116-010-9306-9

Jinsoo Kim. (2012). The role of affect and cognition in the impact of positive/negative online consumer reviews on brand attitude and purchase intention. (Degree of Doctor of Philosophy), University of Florida.

K.C Law, Y. p. L. (2009). Personal loans riskier but have high interest and growth potential. The star. from http://biz.thestar.com.my/news/story.asp?file=/2009/5/26/business/3891051

Karjaluoto, H., Mattila, M., \& Pento, T. (2002). Factors underlying attitude formation towards online banking in Finland. International Journal of Bank Marketing, 20(6), 261-272.

Kasseeah, H. (2012). Financing Decisions of Small and Medium-sized Firms: A Review of Literature. Information Management and Business Review, 4(5), 275-284. 
Kennedy, B. P. (2013). The theory of planned behavior and financial literacy: A predictive model for credit card debt? (3560898 Psy.D.), Marshall University, Ann Arbor. Retrieved from http://search.proquest.com/docview/1366511682?accountid=51152 ProQuest Dissertations \& Theses Global database.

Khali, S., Mahmood, B.,Abbas, M.,\& Hussain. (2011). Customer satisfaction with service quality in conventional banking in Pakistan:The case of Faisalabad. International Journal of Marketing Studies, 3(4). www.ccsenet.org/ijms

Khan, M. (2006). Consumer Behavior and Advertising Management (pp. 391). Retrieved from http://bookzz.org/book/1054938/15e945/?_ir=1

Kim, D. J., Ferrin, D. L., \& Rao, H. R. (2008). A trust-based consumer decision-making model in electronic commerce: The role of trust, perceived risk, and their antecedents. Decision support systems, 44(2), 544-564.

Kim, J. (2009). A consumer shopping channel extension model: attitude shift toward the online store. Journal of Fashion Marketing and Management, 9(1), 106.

Kim, J. B. (2012). An empirical study on consumer first purchase intention in online shopping: integrating initial trust and TAM. Electronic Commerce Research, 12(2), 125-150. doi: http://dx.doi.org/10.1007/s10660-012-9089-5

Kisang Ryu, H.-R. L., \& Kim, W.G. (2012). The influence of the quality of the physical environment, food and service on restaurant image, customer perceived value, customer satisfaction and behavioral intentions International Journal of Contemporary Hospitality Management, 24(2), 200-223.

Konstantinos, N. D. M. (2001). Can perceptions of service quality predict behavioral intentions?An exploratory study in the hotel sector in Greece. Managing Service Quality, 12(4), 224-231.

Kotler, P. (1976). Marketing Management. Englewood Cliffs,NJ: Prentice Hall, Inc

LaBarbera, P. A., \& Marzursky. (1983). A longitudinal assessment of consumer satisfaction/dissatisfaction: the dynamic aspect of the cognitive process. Journal of Marketing Research, 20, 393-404.

Lam, T., \& Hsu. (2006). Predicting behavioral intention of choosing a travel destination. Tourism Management, 27(4), 589-599.

Linville, J. E. (2003). The collective good: The relationship among unionization, perceived control, and overall job satisfaction for faculty in two-year colleges. (3091030 Ed.D.), University of Washington, Ann Arbor. Retrieved from http://search.proquest.com/docview/305278303?accountid=51152 ProQuest Dissertations \& Theses Global database.

Liqiang Chen. (2009). Online consumer behavior: An empirical study based on theory of planned behavior. (Degree of Doctor of Philosophy), University of Nebraska, Lincoln, Nebraska.

Mackenzie, S. H., Hodge, K., \& Boyes, M. (2011). Expanding the Flow Model in Adventure Activities: A Reversal Theory Perspective. Journal of Leisure Research, 43(4), 519544.

Manafi, M., Gheshmi, R., Hojabri, R., \& Fotoohnejad, S. (2011). Mediating role of Customer Satisfaction in Relationships between Employee Satisfaction and Financial Performance. Interdisciplinary Journal of Contemporary Research In Business, 3(7), 782-794.

McDougall, G. H., \& Levesque, T. (2000). Customer satisfaction with services: putting perceived value into the equation. Journal of services marketing, 14(5), 392-410.

McGrath, R. (2001). Exploratory learning, innovative capacity and managerial oversight. Academy of Management Journal, 44(1), 42-63.

MIDA, M. I. D. A. (2012). Invest in Malaysia. Retrieved 21 September 2012, from http://www.mida.gov.my/env3/index.php?page=banking-system 
Min Young Lee, Y. K. K., Lou Pelton, Dee Knight, Judith Forney. (2008). Factors affecting Mexican College student's Purchase intention towards US apparel brand. Journal of Fashion Marketing Management, 12(3), 294-307.

Mittal, V., \& Kamakura,W.A. (2001). Satisfaction, repurchase intent, and repurchase behavior: Investigating the moderating effect of customer characteristics. Journal of Marketing Research, 38(1), 131-142.

Moutinho, L. (1987). Consumer behavior in tourism. European Journal of Marketing, 21, 544.

Muhammad Mohsin, B., \& Aftab, M. (2013). Incorporating attitude towards Halal banking in an integrated service quality, satisfaction, trust and loyalty model in online Islamic banking context. The International Journal of Bank Marketing, 31(1), 6-23. doi: http://dx.doi.org/10.1108/02652321311292029

Muradoglu, G., \& Harvey, N. (2012). Behavioural finance: the role of psychological factors in financial decisions. Review of Behavioral Finance, 4(2), 68-80.

N Anilkumar. (2012). Factors Influencing the Pre-Purchase Attitude of Consumers: A Study. The IUP Journal of Management Research, XI(3).

NAIC (Producer). (2007). United state Census. Retrieved from https://www.census.gov/econ/industry/def/d52.htm

Namkung, Y. J., S. (2007). Does food quality really matter in restaurant?Its impact on customer satisfaction and behavioral intentions. Journal of Hospitality and Tourism Research, $31(3), 387-410$.

Nejatullah. (2002). Comparative advantages of Islamic Banking and Finance. Paper presented at the Harvard University Forum on Islamic Finance, Harvard.

Newell, O. (2009). The development and premilinary performance anaysis of Islamic REITs in Malaysia. Journal of Property Research, 26(4), 329-347.

Newman, J. W., \& Werbel,R.A. (1973). Multivariate analysis of brand loyalty for major household appliance. Journal of Marketing Research, 10, 404-409.

Nguyen, N. T., Tran, T. T., \& Wang, C. N. (2014). An Empirical Study of Customer Satisfaction towards Bank Payment Card Service Quality in Ho Chi Minh Banking Branches. International Journal of Economics and Finance, 6(5), 170-181. doi: http://dx.doi.org/10.1509/jmkg.64.3.50.18024

Nilson, T. H. (1992). Value added marketing: Marketing Management for Superior. Bershire: McGraw-Hill.

Oh, H. (2000). Diner's perception of quality, value, and satisfaction: A practical viewpoint. Cornell Hotel and Restaurant Administrative Quartely, 58-66.

Opperman.M. (1998). Destination threshold potential and the law of repeat visition. Journal of Travel Research, Summer 1995, 63-67.

Pachauri, M. (2001). Consumer behaviour: a literature review. The Marketing Review, 2(3), 319-355.

Pachauri, M. (2002). Researching online consumer behaviour: current positions and future perspectives. Journal of Customer Behaviour, 1(2), 269-300.

Pacheco, N. A., Lunardo, R., \& dos Santos, C. P. (2013). A Perceived-Control Based Model to Understanding the Effects of Co-Production on Satisfaction. Brazilian Administration Review, 10(2), 219-238. doi: 10.1016/0749-5978(91)90020-T

Pantouvakis, A., \& Lymperopoulos,K. (2008). Customer satisfaction and loyalty in the eyes of new and repeat customers: Evidence from the transport sector. Managing Service Quality, 18(6), 623-643.

Parasuraman, a., zeithaml. (1988). SERVQUAL: a multiple item scale for measuring consumer perception of service quality. journal of retailing, vol49(no.4), pp.41-50. 
Park, J., \& Ha, S. (2012). Understanding pro-environmental behavior: a comparison of sustainable consumers and apathetic consumers. International Journal of Retail \& Distribution Management, 40(5), 388-403.

Parker, C., \& Mathews, B.P. (2001). Customer satisfaction: contrasting academic and consumers' interpretations. Marketing Intelligence \& Planning, 19(1), 38-44.

Patrick, S. (Producer). (1999). What Drives the Performance of Financial Institutions? Retrieved from http://fic.wharton.upenn.edu/fic/papers/98/9821.pdf

Patterson, P. G., \& Spreng,R.A. (1997). Modelling the relationship betwen perceived value,satisfaction and repurchase intentions in a business to business, service context: an empirical examination. International Journal of Service Industry Management, 8(5), 414-434.

Pavlou, P. A., \& Fygenson, M. (2006). Understanding and predicting electronic commerce adoption: an extension of the theory of planned behavior. MIS quarterly, 115-143.

Pavlou, P. A., \& Gefen, D. (2004). Building effective online marketplaces with institutionbased trust. Information Systems Research, 15(1), 37-59.

Perry, V. G., \& Morris, M. D. (2005). Who Is in Control? The Role of Self-Perception, Knowledge, and Income in Explaining Consumer Financial Behavior. The Journal of Consumer Affairs, 39(2), 299-313.

Petty, R. E., Unnava, R.,\& Stratham, A. (1991). Theories of attitude change. New York: Prentice Hall.

Politz, A. (1958). Motivation Research-Opportunity or Dilemma? Ferber, Robert \& Wales, Hugh C. Motivation and market behavior. Homewood, 111, 50.

Polkinghorne, D. E. (1992). A postodernism epistemology of practice. London: Sage.

Rigdon, E. E. (1996). CFI versus RMSEA: A comparison of two fit indexes for structural equation modeling. Structural Equation Modeling: A Multidisciplinary Journal, 3(4), 369-379.

Roubaie, A. A. (2009). A bulwark against contagion in the global banking system. Islam and Civilisation Renewal, 303-321.

Ruthig, J. C. (2005). Relationship perceptions: Effects of perceived control, efficacy, and optimism on relationship satisfaction and longevity. (NQ97305 Ph.D.), The University of Manitoba (Canada), Ann Arbor. Retrieved from http://search.proquest.com/docview/305402639?accountid=51152 ProQuest Dissertations \& Theses Global database.

Ryu, K. J., S.C. (2007). The effect of environment perceptions on behavioral intentions through emotions: The case of upscale restaurants Journal of Hospitality \& Tourism Research, $31-56$.

Saiful, A. (2003). Performance of Islamic and mainstream banks in Malaysia. International Journal of Social Economies, 30(12).

Samad, A., Garner, Norman and Cook. (2005). islamic banking and finance in theory and practice: he experience of malaysian and bahrain. american journal of islamic social sciences, 22.

Santos, J. A. C. (2000). Bank capital regulation in contemporary banking the theory: Review of the literature BIS working paper. Basel.

Sekaran, U. (2005). Research methods for business: a skill building approach. New York: John Wiley \& Sons, Inc.

Sentosa, I., \& Mat, N. K. N. (2012). Examining a theory of planned behavior (TPB) and technology acceptance model (TAM) in internetpurchasing using structural equation modeling. Researchers World, 3(2 Part 2), 62-77.

Servon, L. J., \& Kaestner, R. (2008). Consumer Financial Literacy and the Impact of Online Banking on the Financial Behavior of Lower-Income Bank Customers. The Journal of Consumer Affairs, 42(2), 271-305. 
Shafie, S. (2004). Adopting and measuring customer service quality in Islamic Banks: A case study of Bank Islam Malaysia Berhad. Journal of Muamalat and Islamic Finance Research, 1(1).

Shahzad Khan. (2012). Factors responsible for making consumer attitude towards islamic banking A Study of Islamic Banks Accountholders of Peshawar Region Pakistan. Arabian Journal of Business and Management Review (OMAN Chapter) Vol. 2, No.1; Aug 2012, 2(1).

Shannon. (2009). Consumer Credit Card Behavior in South Dakota: A Pilot Investigation. (Doctor of Philosophy), South Dakota State University, South Dakota State Retrieved from

http://search.proquest.com/docview/304996190/fulltextPDF/CA2D5B0C95334953PQ $/ 1$ ? accountid=51152

Shefrin, H. (2008). A behavioral approach to asset pricing: Academic Press.

Sheth, J. N., \& Parvatlyar, A. (1995). Relationship marketing in consumer markets: antecedents and consequences. Journal of the Academy of marketing Science, 23(4), 255-271.

Siddiqi, K. O. (2011). Interrelations between Service Quality Attributes, Customer Satisfaction and Customer Loyalty in the Retail Banking Sector in Bangladesh. International Journal of Business and Management, 6(3), 12-36.

Soderlund, M., \& Rosengren,S. (2004). Dimantling "positive affect" and its effects on customer satisfaction: An empirical examination of cusotmer joy in a service encounter. Journal of Customer Satisfaction, Dissatisfaction and Complaining Behavior, 17, 27-41.

Soteriov, A. C. C., R.b. (2000). A robust optimization approach for improving service quality. Journal of Manufacturing and Service Operation Management 264-286.

Sotiropoulos, V., \& D'Astous, A. (2013). Attitudinal, Self-Efficacy, and Social Norms Determinants of Young Consumers' Propensity to Overspend on Credit Cards. Journal of Consumer Policy, 36(2), 179-196. doi: 10.2139/ssrn.2200927http://dx.doi.org/10.1007/s10603-013-9223-3

Spedding, B. (2012). The impact of stigma and social norms on treatment seeking behaviors for mental health issues for the elderly in the United States. (3545582 D.H.A.), Central Michigan University, Ann Arbor. Retrieved from http://search.proquest.com/docview/1240666959?accountid=51152 ProQuest Dissertations \& Theses Global database.

Stepanova, M., \& Thomas, L. (2002). Survival analysis methods for personal loan data. Operations Research, 50(2), 277-289.

Tajudin, A. A. (2010). Islamic Finance Course: Structure \& Instruments. Bank Negara Malaysia. www.ucti.edu.my/wps/issue1/wp-06-06-paper.pdf

Takagi, N. I. (2009). Flow theory: Conscious experience in expository argumentative writing. (3368057 Ph.D.), Case Western Reserve University, Ann Arbor. Retrieved from http://search.proquest.com/docview/304850251?accountid=51152 ProQuest Dissertations \& Theses Global database.

Thaler, R. (1985). Mental accounting and consumer choice. Marketing science 4, 199-214.

Tian-Cole, S., Crompton,J,L .,Wilson,V.L. (2002). An empirical investigation on the relationships between service quality. Journal of Leisure Research, 34(1), 1-24.

Trafimow, D. (1999). Influencing future behavior by priming past behavior: A test in the context of Petrified Forest national park. Leisure Science, 21, 31-42.

Trenton Milner, Daniela Rosenstreich. (2013). Insights into mature consumers of financial services. Journal of Consumer Marketing.

Tull, D. S. H., D.I. (1987). Marketing research: Measurement and method New York: Macmillan Pub.co.

W.Alsultan, M., M.,\& Roudaki, J. (2005). Financial analysis of performance of Islamic Banks in GCC countries. Journal of Islamic Banking and Finance, 51-65. 
http://www.webmeets.com/files/papers/SAEe/2011/12/paper_share_performancefinal. pdf

Wang, H., Y.V. (2003). The antecedents of service quality and product quality and their influences on bank reputation: evidence from banking industry in China. Managing Service Quality, 13(1), 72-83.

Wang Lili, Lv Wei, \& Jiang Lin. (2011). The impact of attitude variables on the credit debt behavior. Nankai Business Review International, 2(2), 120-139.

Wayne D. Hoyer, D. J. M. (2007). Consumer Behavior, Fifth Edition. South-Western: Nelson Education, Ltd.

Weber, J. C. d. V. (2002). Differences in purchase behavior between France and the USA: The cosmetic industry. Journal of Fashion Marketing Management, 6(4), 396-407.

Wikipedia. (2014). Personal Finance. from http://en.wikipedia.org/wiki/Personal_finance

Yagil, D. (2002). The relationship of customer satisfaction and service workers' perceived control: Examination of three models. International Journal of Service Industry Management, 13(3/4), 382-398.

Yonggui, H.-P. L. (2002). Service quality, customer satisfaction and behavior intentions: Evidence from China's telecommunication industry. 4(6), 50-60.

Yoon, Y., \& Uysal,M. (2005). An examination of the effects of motivation and satisfaction on destination loyalty:A structural model. Tourism Management, 26, 45-46.

Young, R. A., \& Kent, A. (1985). Using the theory of reasoned action to imporve the understanding of recreaction behavior. Journal of Leisure Research, 17, 90-106.

Zeithaml, V. A. (1988). Consumer perseptions of price, quality, and value: A measurement model and synthesis of evidence. Journal of Marketing Research, 52(3), 2-22.

Zuroni. (2012). Personal Financial Knowledge and Attitude towards Credit Card Practices among Working Adults in Malaysia. International Journal of Business and Social Science, 3(7). 